\title{
Changes in Chemical Composition of Soluble Organic Chemical Compounds during Litters Decomposition into Tropical Forest of Milletia laurentii De Wild
}

\author{
Gouolaly Tsiba1,2, Mavoungou Naïving Flovique Rosère ${ }^{3}$, Edzonga Josianne ${ }^{4}$, \\ Milandou Matoko Jodhry Préféré3, Malonga Urielle Marini' ${ }^{3}$, Madingou Parfait Noé ${ }^{3}$, \\ Binsangou Stoffenne ${ }^{3}$, Ifo Suspense Averti ${ }^{3 *}$
}

\begin{abstract}
${ }^{1}$ National Institute for Research in Health Science, Department of Pharmacopeia and Folk Medicine Chemistry, Organic Biomolecules and Pharmacodynamics Laboratory, Brazzaville, Republic of Congo

${ }^{2}$ Sciences and Technologies Faculty, Marien Ngouabi University, Brazzaville, Republic of Congo

${ }^{3}$ LGETA, ENS, Marien Ngouabi University, Brazzaville, Republic of Congo

${ }^{4}$ ENSAF, Marien Ngouabi University, Brazzaville, Republic of Congo

Email: *averti.ifosuspens@umng.cg
\end{abstract}

How to cite this paper: Tsiba, G., Rosère, M. N. F., Josianne, E., Préféré, M. M. J., Marini, M. U., Noé, M. P., Stoffenne, B., \& Averti, I. S. (2019). Changes in Chemical Composition of Soluble Organic Chemical Compounds during Litters Decomposition into Tropical Forest of Milletia laurentii De Wild. Open Journal of Forestry, 9, 70-87. https://doi.org/10.4236/ojf.2019.91003

Received: November 28, 2018

Accepted: January 22, 2019

Published: January 25, 2019

Copyright $\odot 2019$ by author(s) and Scientific Research Publishing Inc. This work is licensed under the Creative Commons Attribution International License (CC BY 4.0).

http://creativecommons.org/licenses/by/4.0/

\begin{abstract}
Recent publication attested that in the urban forest of Brazzaville, litter decomposition is faster with almost $45 \%$ of initial weight loss than in the dry season, where an average loss of $26 \%$ in initial litter weight is noted (Ifo et al., 2018). This study was carried out in the urban forest of Brazzaville to follow the decomposition of some organic compounds/secondary metabolites (reducing Sugars, total Flavonoid and Polyphenols) of the leaves litters of two tropical species Antiaris toxicaria Lesch and Millettia laurentii De Wild. Thin-layer chromatography and spectrophotometric assay of these metabolites were used on the samples of litters collected in the field on various dates of follow-up of the decomposition $(0 \mathrm{~d}, 14 \mathrm{~d}, 28 \mathrm{~d}, 42 \mathrm{~d}, 56 \mathrm{~d}, 72 \mathrm{~d}$ and $84 \mathrm{~d}$ ). The chromatographic profile of initial litters shows a series of spots on yellow florescence materializing presence of flavonoids, green fluorescence revealing the presence of the acids phenols derived from the cinnamic acid. But the chromatographic profile of the two litters in decomposition after two weeks remains without structural information, being able to characterize the decomposition of the chemical families highlighted in the initial litters. Also, the analysis of quantitative total reducing sugar in the initial litters, gives average concentrations of $64.4,58.6,57.5 \mathrm{~g} \mathrm{EG} / \mathrm{kg}$ Ms respectively for the litters of Millettia laurentii De Wild, Antiaris toxicaria Lesch and the mixed litters (Millettia laurentii and Antiaris toxicaria). Comparatively with the other
\end{abstract}


types of litters, the initial average concentrations in phenolic compounds (polyphenols and flavonoids totals) were the highest for the litters of Antiaris toxicaria Lesch (27.3 g EAG/kg Ms and $13.07 \mathrm{~g} \mathrm{EC} / \mathrm{kg} \mathrm{Ms})(P=0.001)$. The losses of organic chemical compounds are more significant during the first two weeks of experiment than after this period. Antiaris toxicaria Lesch loses on average $43.8 \mathrm{~g} \mathrm{EG} / \mathrm{kg}$ Ms of reducing Sugars, $12.21 \mathrm{~g} \mathrm{EC} / \mathrm{kg} \mathrm{Ms}$ of totals

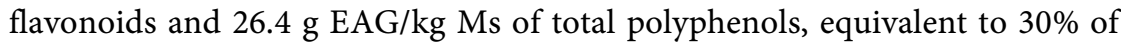
loss of the initial weight. Average losses of $45.7 \mathrm{~g} \mathrm{EG} / \mathrm{kg}$ Ms were obtained for reducing sugars, $1.5 \mathrm{~g} \mathrm{EC/kg} \mathrm{Ms} \mathrm{for} \mathrm{totals} \mathrm{flavonoids} \mathrm{and} 8.72 \mathrm{~g}$ EAG/kg Ms for totally phenols in for the litters of Millettia laurentii, comparable to $24 \%$ in initial weight loss. This study showed on the one hand, the direct link between rainfall and litters decomposition and the losses in weight of the litters resulted in dissolution in the water of the studied compounds.

\section{Keywords}

Tropical Urban Forest, Litter Decomposition, Organic Chemical Compounds

\section{Introduction}

Tropical forests play many functions, including attenuation of global warning effects through the sequestration of carbon in the atmosphere. They contain an important aboveground biomass stock of carbon (IPCC, 2006; Lewis et al., 2009) and are teeming with very large plant biodiversity (de Wasseige et al., 2015; Ifo et al., 2016).

Apart from these large forest areas which extend over millions of square kilometers, there are in many places in the tropics, and within cities, urban forests. They are defined as the sustainable development of trees in an urban society and consist of trees and shrubs of natural or anthropogenic origin located within the limits of a city (FAO, 2010).

Thus, urban forests are ecosystems with trees and other plants lying in streets, courtyards, parks, and spaces surrounding large cities. In recent decades, research has shown that urban trees are an integral part of the environmental quality of cities around the world (Bolund \& Hunhammar, 1999; Dwyer et al., 1991). Urban trees and their soils are likely to reduce urban runoff frequencies. Similarly, urban areas are often hot spots for air pollution from the automotive industry (Garty et al., 1996).

In the global context of fighting global warming, understanding how urban forests work and how these forests can participate in both mitigation and adaptation to global warming, will help to preserve on one hand, and on the other hand to increase their intra-urban areas.

Among the compartments of sustainable carbon sequestration, there is the soil compartment with carbon allocation either by rhizodeposition or by decomposition of leaf litter. Litter decomposition is a key step of the passage of bio ele- 
ments as well as other organic compounds from wood-compartment trees to the soil compartment. Leaves litters play an important role in the functioning of forest ecosystems through the recycling of bio elements but also in the carbon cycle through the release of organic compounds during litters' decomposition (Bernhard-Reversat, 1993; Ibrahima et al., 2008; Jeyanny et al., 2015). Decomposition of leaves litters promotes also the maintenance of soil fertility and conditions of soil structure (Babel, 1971; Zeller, 1998). During this process, immobilized nutrients in litter are released from litter to soil and made available to plants and soil micro-organisms (Waring \& Schlesinger, 1985).

In addition, the variability in the rate of the decay of leaf litter, both from one species to another, from one site to another, or from one type of climate to another (Bernhard-Reversat et al., 2000; Diallo et al., 2016) and the variability in decay rates were related to litter quality, site conditions, and environmental action (Torreta \& Takeda, 1999). Additionally, it was established that in the rainforest ecosystem the decay of litter's leaves is very fast (Bernhard-Reversat et al., 1979; Swift et al., 1979; Ifo \& Nganga, 2011; Ifo et al., 2018). But the interpretation of variability in litter decay rates requires more information on the effects of soil fauna, litter quality, moisture and drying, micro flora (bacteria, fungus) on the litter decomposition (Garay et al., 1986; Loumeto, 2002; Goma-Tchimbakala \& Reversat, 2006; Ifo \& Nganga, 2011; Ifo et al., 2018). Bernhard-Reversat (1993) reported that weight loss from fresh litter was equal to the loss of soluble compounds during the first weeks of in situ decay. Also, the effect of litter quality on the decay rate has been studied by several authors in different types of forest ecosystems (Bargali et al., 1993; Cornelissen, 1996; Ifo et al., 2018). But much less attention was given to changes in the organic chemical composition of leaf litter during the process of decomposition of organic matter mainly in the natural tropical forest of Congo Basin.

However, it important to note that, existing studies in republic of Congo and in the rest of the world on dynamic of leaching of chemical organic compounds been done in Eucalypt and Acacia plantations (Bernhard-Reversat, 1993; Bernhard-Reversat, 2000; Bernhard-Reversat et al., 2003), in natural forest (Anderson \& Swift, 1983; Bernhard-Reversat \& Schwartz, 1997). The results obtained in these studies revealed that the chemical organic compounds control the weight loss of plant litter, early nitrogen and phenols at the end of decay (Diallo et al., 2016). Phenolic compounds are generally considered recurrent to decay and inhibit nitrogen mineralization (Ngao et al., 2009). Among the organic compounds, carbohydrates are easily and rapidly leached. They are generally easily and rapidly degraded in early stages of litter decomposition by fast growing microorganisms that may require a high concentration of nitrogen (Swift et al., 1979). Cellulose and lignin, the most abundant components of litter, are slowly decomposed. High concentrations of polyphenols and lignin lead to low decomposition rate (Swift et al., 1979; Kalburtji et al., 1999).

These different chemical compounds in litters contain significant amounts of carbon. Monitoring their leaching dynamics would help to understand how the 
carbon cycle can vary from one season to another during the year, notably the influence of the season on the transfer of carbon contained in the air compartment to the reservoir ground by following the decay dynamics of the litters during the dry season, or during the rainy Season.

The forest at Millettia laurentii is widely widespread in Brazzaville and its environs and more especially in the Batekés plateaux. It is characteristic of an intermedia state of progressive evolution towards the climax, a stage that characterized by the dominance of Parinari excelsa understanding, the functioning of the forests in Millettia laurentii of the city of Brazzaville will allow to have significant information on the operation of this type of forest that spread over hundreds of hectares in the center of the Republic of the Congo as well as in the Congo forest Basin.

The general aim of this study is to improve knowledge of the functioning of tropical forest ecosystems, and the specifics objectives were: a) to determine the initial contents of the following organic chemical compounds: reducing sugars, flavonoids and total polyphenols in the litters of the main forest species of the urban forest of Brazzaville, b) monitor the dynamics of the losses of these organic chemical compounds as a function of time during the rainy season.

\section{Materials and Methods}

\subsection{Presentation of the Study Area}

The forest of the Zoological Park of Brazzaville is in the center of Brazzaville's city closed to Maya Maya Airport" (Figure 1). This forest belongs to the domain of Lower Guinea and the Congolese-Zambesien transition sector of the District of La Lefini whose forests are mostly mesophilic. The natural forest is dominated by Millettia laurentii De Wild. The climate of Brazzaville called "low Congolese climat" is characterized by annual averages of temperature of approximately $25^{\circ} \mathrm{C}$ and annual thermal amplitude oscillating from $4{ }^{\circ} \mathrm{C}-6^{\circ} \mathrm{C}$. March and April are the hottest months, while months from June to September is considering as a dry season. The rainfall season varies from October to May and the average rainfall is of approximately $1200 \mathrm{~mm}$ year ${ }^{-1}$. The maximum of rainfall was observed in March-April and in November-December (Figure 2). The relative humidity is higher than $70 \%$.

The annual average varies between 1100 and $1800 \mathrm{~h}$ for the same period. The soils are ferralitic, strongly desaturated and impoverished. They are low in exchangeable and very permeable bases because of the sandy substrate which allows the migration of the solutions of the ground.

Depending on its geographical location, the urban forest of the zoological park of Brazzaville is dominated by the subtropical climate. The average annual rainfall is $1500 \mathrm{~mm}$ and the average annual temperature is $26^{\circ} \mathrm{C}$ (Ifo et al., 2016). Relative humidity is still high at $80 \%$ on average. This site is also characterized by ferralitic soils with a sandy texture and therefore poor in clay with a content of less than $20 \%$. Chemical analysis of these soils reveals relatively low levels of organic matter $(2.5 \%)$ and a $\mathrm{C} / \mathrm{N}$ ratio $\leq 12$. On the phytogeographic area, 


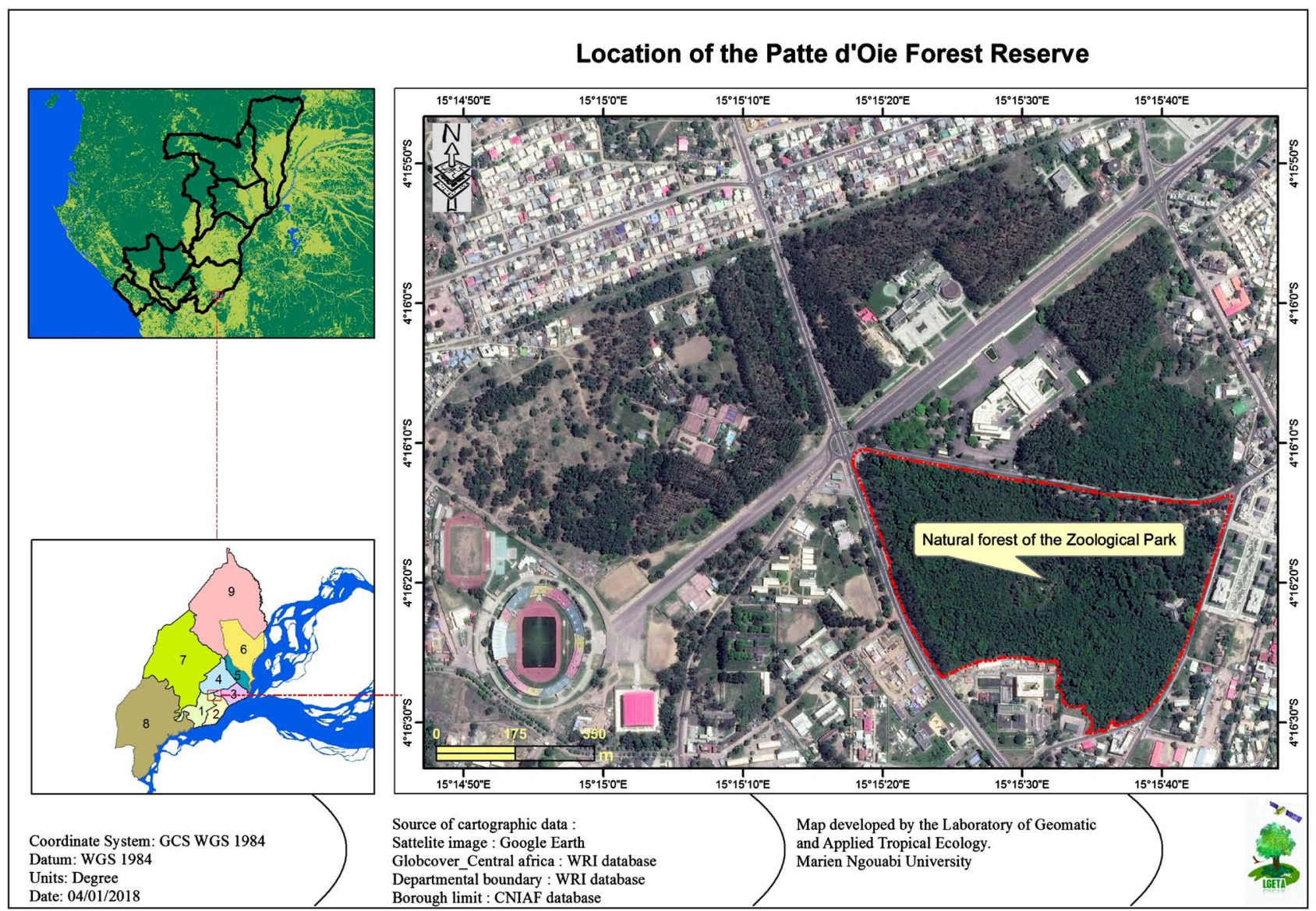

Figure 1. Study area location of the urban natural forest of Brazzaville.

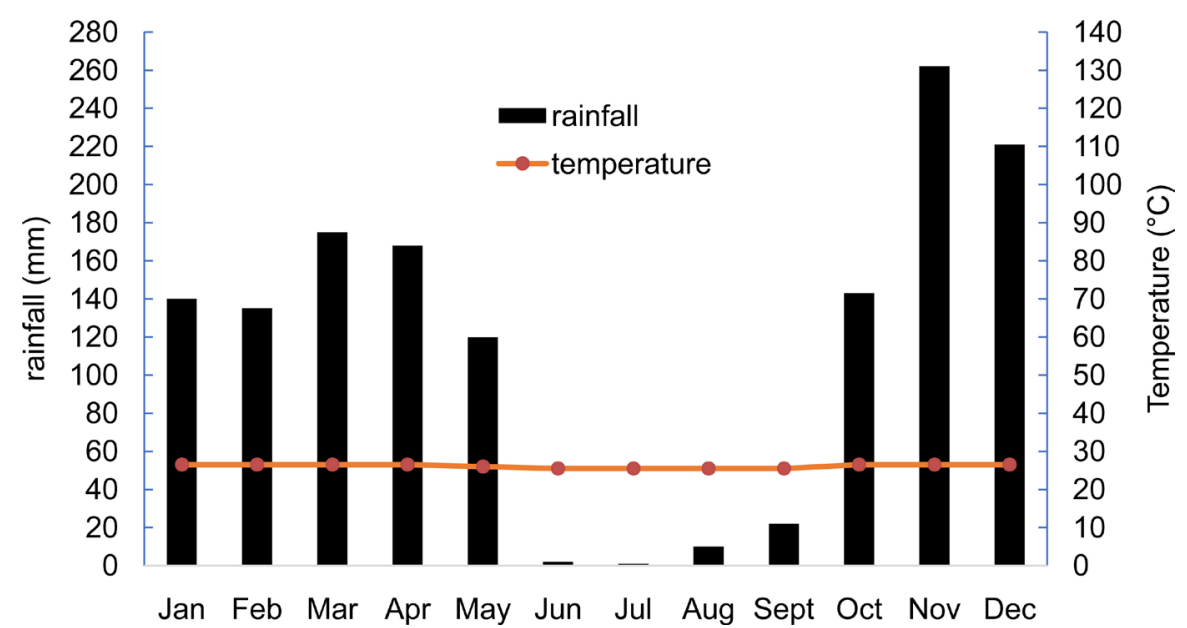

Figure 2. Ombrothermic Diagram of the Brazzaville's city from 1960-2014, ANAC Brazzaville.

the urban forest of the of Brazzaville belongs to the domain of Lower Guinea and the Congolese-Zambézienne transition area of the District of Léfini (Koubouana et al., 2016) whose forests are mostly mesophilic. Most of this forest is dominated by the species belonging to the Fabaceae, Moraceae, Loganiaceae, Rubiaceae and Euphorbiaceae's families (Taty \& Mombouli, 1998). 


\subsection{Litter Fall Sampling}

The measurements of the litter fall were estimated by randomly placing eight litter fall traps in all the study area, each trap measuring $50 \mathrm{~cm} \times 50 \mathrm{~cm}$ with $2 \mathrm{~mm}$ nylon mesh to catch the litter and located $50 \mathrm{~cm}$ above the ground. Litter was collected from the traps at two-week intervals for from August 2016 to $17 \mathrm{Au}$ gust 2017. The collected litter samples were brought to the laboratory, separated into leaf and non-leaf components and oven-dried at 70EC for four days to constant weight, using an electronic balance (CS200, Ahaus $0.1 \mathrm{~g}$ accuracy).

\subsection{Litter Decomposition Experiment}

Mesh litter bags containing leaves were placed into random locations within the plots and retrieved them after varying lengths of time to quantify litter decomposition rates. The experiment was repeated two times, one experiment in the dry season from august to earlier October 2016. The second experiment was done during the rainfall season from December to March and the leaves of the most dominant tree species in their respective stands were put into the litter bags (Zeller, 1998; Bernhard-Reversat et al., 2000; Ifo, 2010; Zouaoui et al., 2013; Sabin Nguedehou et al., 2014; Diallo et al., 2015). The litter bags were made of $2 \mathrm{~mm}$ nylon mesh, sized $20 \times 20 \mathrm{~cm}$. In the secondary forest each litterbag contained, $10 \mathrm{~g}$ of pure litters of Milletialaurentii and in the gallery forest $10 \mathrm{~g}$ of pure litters of Antiaris toxicaria the leaves for the experiment were sourced from recently fallen Antiaris toxicaria and Milletia laurentii within the study plots. About $10 \mathrm{~g}$ of mix litter of both two kinds of litter cited above. 144 nylon-net bags ( $2 \mathrm{~mm}$ mesh) of $20 \times 20$ $\mathrm{cm}$ were prepared for each experiment. Forty-eight of each types of litter were placed in the forest of "Patte d'oie" to follow the litter decay dynamics. Eight bags of each type of litter were collected once every two weeks for three months. This was repeated 3 times as mentioned it above. After recovery from the forest, the bags were placed in individual polythene bags and brought to the laboratory. The bags were opened, and the litter materials were air dried initially, brushed to remove adhering soil particles and finally dried at $70^{\circ} \mathrm{C}$ for four days to constant weight, using an electronic balance $(0.01 \mathrm{~g})$. The percentage of weight loss and decay rate over time was fitted using a following expression:

$$
\begin{gathered}
P_{m}(\%)=100 \times \frac{\left(P_{i}-P_{f}\right)}{P_{i}} \quad \text { (GUO \& SIMS, 1999) } \\
k^{\prime}=\frac{1}{t} \ln \left(\frac{M_{0}}{M_{t}}\right) \quad \text { (Olson, 1963), }
\end{gathered}
$$

\subsection{Chemical Analyses of Litters}

\subsubsection{Preparation of the Extract of Leaves Litters}

After grinding and sieving of the litter samples of Antiaris toxicaria Lesch, and Millettia laurentii de Wild and mixed litters of the two litters, the powder obtained is stored in vials labeled with the date of withdrawal of the samples from 
the field, and the codification of the type of litter considered. $2 \mathrm{~g}$ of plant material is mixed with $2 \times 20 \mathrm{ml}$ of a $50 \%(\mathrm{~V} / \mathrm{V})$ hydro-methanol solution or $50 \%$ $(\mathrm{V} / \mathrm{V})$ hydro ethanol. The mixture is agitated for 2 hours and then filtered. The filtrate obtained is kept $\operatorname{cool}\left(+4^{\circ} \mathrm{C}\right)$ waiting to be analyzed.

\subsubsection{Chemical Analysis of Litter's Leave}

The extracts of the three types of litter were analyzed qualitatively by silica thin-layer chromatography (Wagner \& Bladt, 1996; Huang et al., 2005). The determination of total soluble sugars is carried out according to the colorimetric method of the throne in sulfuric medium (Bachelier \& Gavinelli, 1966; Pansu, 1992). Then Flavonoids were evaluated by conventional method colorimetry. The protocol used is based on that described by Zhishen et al., 1999 and Kim et al., 2003, with some modifications. Finally, the determination of the total polyphénols was carried out but the method of Folin Ciocalteu (Hogan et al., 2009; Segade et al., 2008; Waterhouse, 2001). However single negative exponential decay model (Olson, 1963) widely applied in decomposition was also fitted to the remaining Reducing sugar, Flavonoids and Polyphenolic compounds which enabled determining the specific decay rate $\left(\mathrm{k}_{\mathrm{s}}\right)$ of each chemical compound.

\subsection{Statistical Analysis}

The extracts of studied litters underwent each one three treatments, according to the period of sampling. The results of analyses were compared by the law of student opposite, according to the probabilities $\mathrm{P}=0.01, \mathrm{P}=0.05$ and $\mathrm{P}=0.001$ and with the degree of freedom $\mathrm{ddl}=4$. The calculated value of $\mathrm{t}(\mathrm{obs})$ is compared with the appropriate critical value of with 4 degrees of freedom. The significant difference is set for $t(o b s)>t$.

\section{Results}

\subsection{The Loss of Litter Weight}

The dynamics of the loss of litter weight with time showed that all the three types of litters samples had a significant loss of the weight compared to the initial weight which was of $10 \mathrm{~g}$. Two weeks after the deposit of the litter bags in the field, the litters of Antiaris toxicariaLesch lost $30 \%$ of the initial weight, while the litters of Millettia laurentii De Wild and mix litters lost 24\% and 19\% of their initial weight respectively. At the end of the experimental period, the litters of $A n$ tiaris toxicaria Lesch lost $53 \%$ of their initial weight against $48 \%$ and $34 \%$ for the litters Millettia laurentii De Wild and mixte litters respectively (Figure 3).

\subsection{Temporal Evolution of the Rate of Decomposition of the Litters}

The monthly coefficient of decomposition $\mathrm{k}^{\prime}$ was calculated. $\mathrm{k}^{\prime}$ value varies strongly between species but also between months. $K^{\prime}$ value decreases from first month to the third month. We noted that decomposition remains very high for the litter of Antiaris toxicaria $\left(k^{\prime}=0.73\right)$ in comparison with the litter of Millettia 
laurentii $\left(k^{\prime}=0.26\right)$ one month after the beginning of experimental design (Table 1). $\mathrm{k}$ ' values were 3 times less important after three months of experimentation for Antiaris toxicaria litters, while k value was two times less important for the litters of Millettia laurentii.

\subsection{Chemical Analysis of Litters}

\subsubsection{Initial Organic Chemical Compounds in the Plant Litters}

The chromatographic profiles on thin layer of monospecific litters of Antiaris toxicaria Lesch and Millettia laurentii De Wild, let firstly see the spots of yellow-orange fluorescence to the frontal retentions at 0.7 and 0.3 , yellow-clear $(0.9$ and 0.4 ) and yellow-green ( 0.35 and 0.6$)$ materializing the presence of flavonoids in the initial samples of litters, secondly a green-clear fluorescence with a frontal retention of (0.2) revealing the presence of an acid phenol in the litter of Antiaris Toxicaria Lesch. Those of the litters in decomposition after two weeks, showed a smudge characterizing the total leaching of the chemical compounds highlighted in the initial litters, except for the litter of Antiaris toxicaria Lesch which have showed a spot of blue fluorescence to a frontal retention (0.8). Initial content of

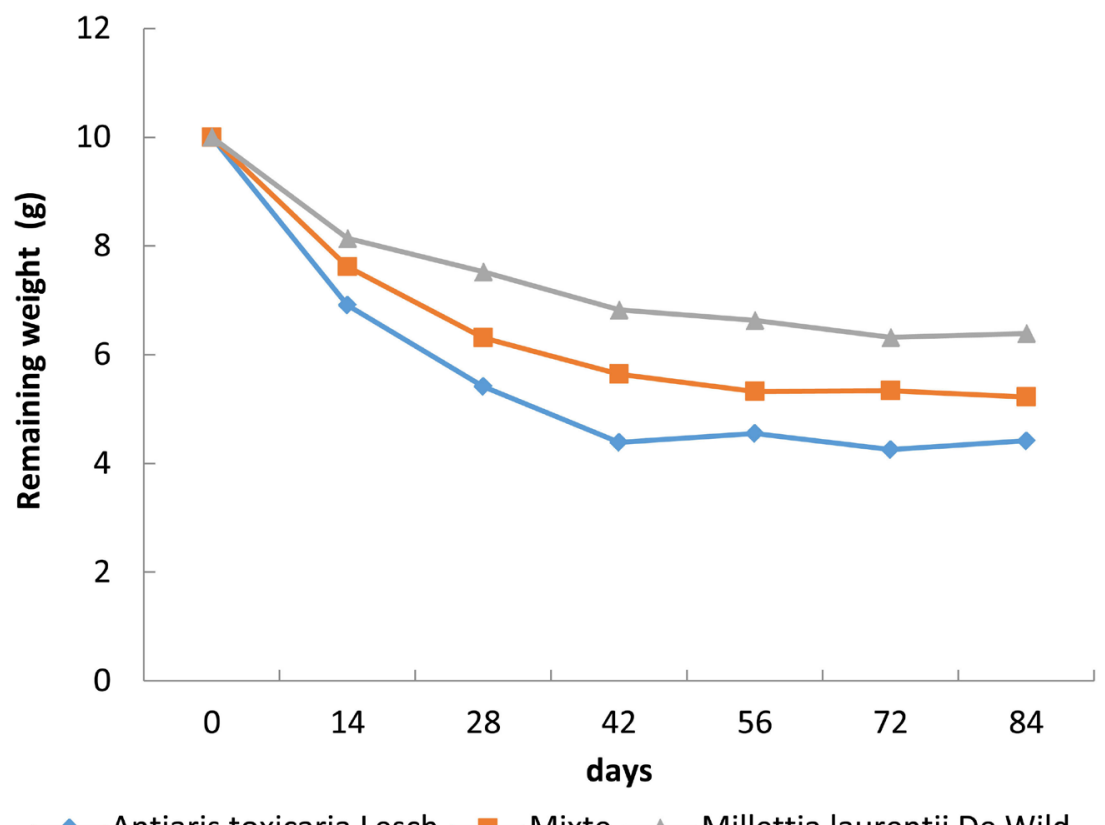

Figure 3. Trends of kinetic of the litter decomposition in mass remaining (g) of litter of different type of litter during rainy season.

Table 1. Values of the monthly coefficient of decomposition $\mathrm{k}^{\prime}$ of the studied litters.

\begin{tabular}{cccc}
\hline \multirow{2}{*}{ Types of litter } & \multicolumn{3}{c}{ monthly coefficient of decomposition k' } \\
\cline { 2 - 4 } & $1^{\text {st }}$ month & $2^{\text {nd }}$ month & $3^{\text {rd }}$ month \\
\hline Antiaris toxicaria Lesch & 0.73 & 0.49 & 0.25 \\
Mixte & 0.49 & 0.29 & 0.21 \\
Millettia laurentii De Wild & 0.26 & 0.21 & 0.14 \\
\hline
\end{tabular}


each chemical organic family of trees species was reported in Figure 4.

\subsubsection{Dynamics of the Loss of the Chemical Organic Compounds of the Litters}

The initial contents of the three chemical families in the foliar litters were presented into Figure 5. The test of student applied to these results shows a very significant difference in the reducing sugar concentration of the monospecific litters on the one hand, and the monospecific and mixte specific litters on the other hand. The concentration out of Polyphenols of the monospecific litters (Millettia laurentii De Wild and Antiaris toxicaria Lesch) as for it, present difference significance only for one probability $P=0.001$. The same observation was made for the concentration of flavonoids for the monospecific litters.

However, a remarkable fact observed, was the rapid loss of the three types of organic chemical compounds found in the foliar litters during the decomposition period. Two weeks after the deposit of the leaves litters, litters lose $66 \%$ of the reducing sugar rates in the mixed litters compared to the initial rates, whereas

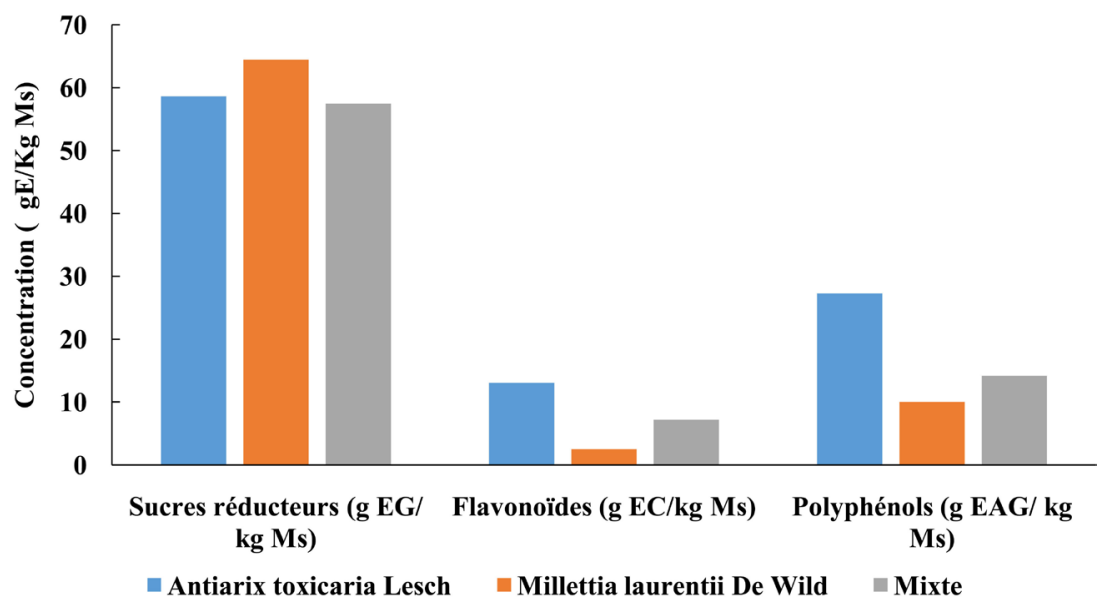

Figure 4. Proportions in flavonoids, polyphenols and sugars of the initial litters.

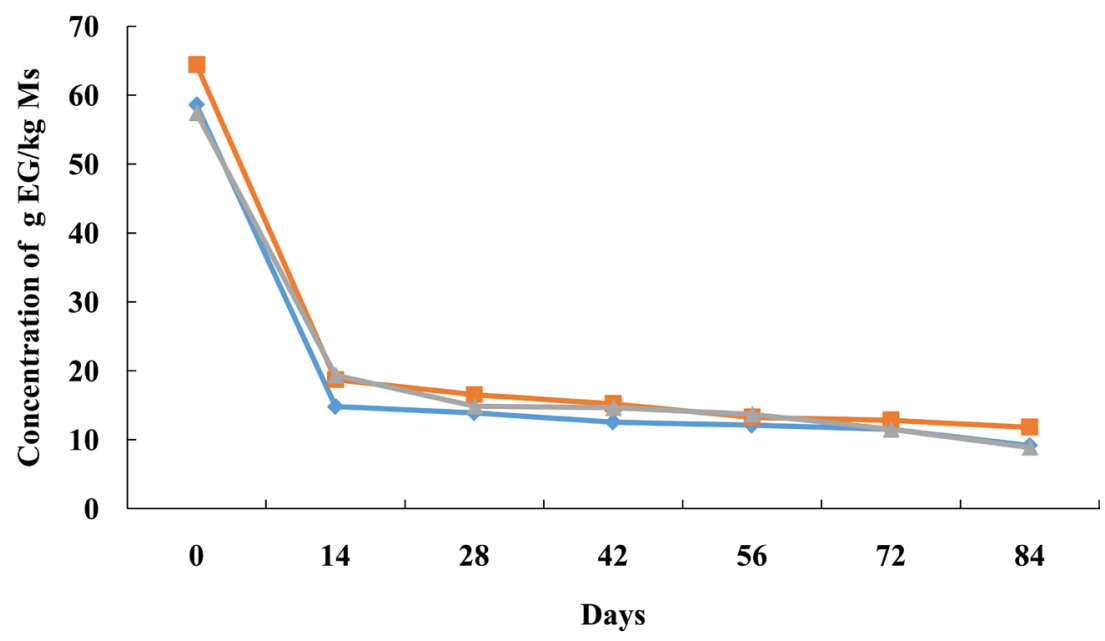

$\longrightarrow$ Antiarix toxicaria Lesch $\rightarrow$ Millettia laurentii De Wild $\longrightarrow$ Mixte

Figure 5. Trends of loss of reducing sugars during experimental period. 
this loss was $70 \%$ for the litters of Millettia laurentii and $74 \%$ of loss compared to the initial rate in the litters of Antiaris toxicaria. The loss of total flavonoids follows the same speed of loss as reducing sugars with a loss of 59\% in the litters of Millettia laurentii against $92 \%$ of loss in the litters Antiaris toxicaria. The loss of the total polyphenols (flavonoids, acid phenols, tanin, etc.) was also significant after two weeks, with $96 \%$ of loss for the litters of Antiaris toxicaria against $87 \%$ of loss for the foliar litters of Millettia laurentii. After rapid period of high-speed leaching, the loss of organic chemical compounds is continual and slow until the end of the experience (Figures 5-7).

Within a species, each chemical compound (Reducing Sugars, Flavonoids, Polyphenols) decomposed according to its own decay rate ( $k$ specific, $k s$ values). $k s$ values varied within and between species. The highest $k s$ values were identified in Polyphenol (Table 2) followed by Flavonoid.

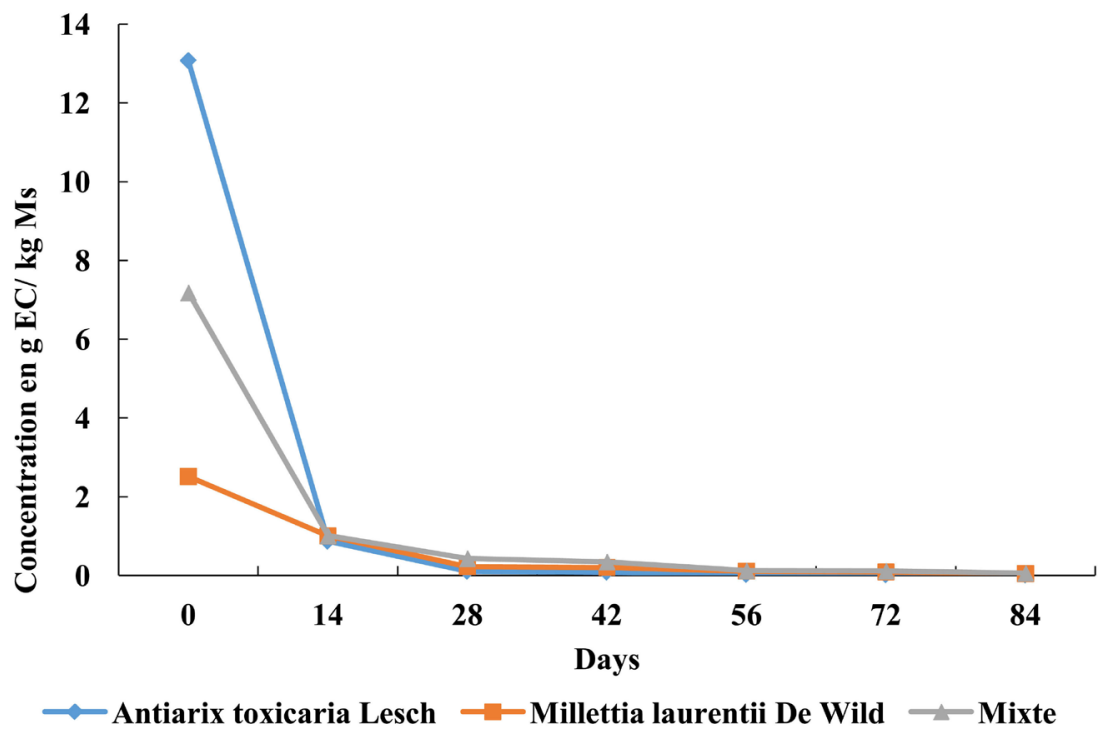

Figure 6. Trends of loss of flavonoids during experimental period.

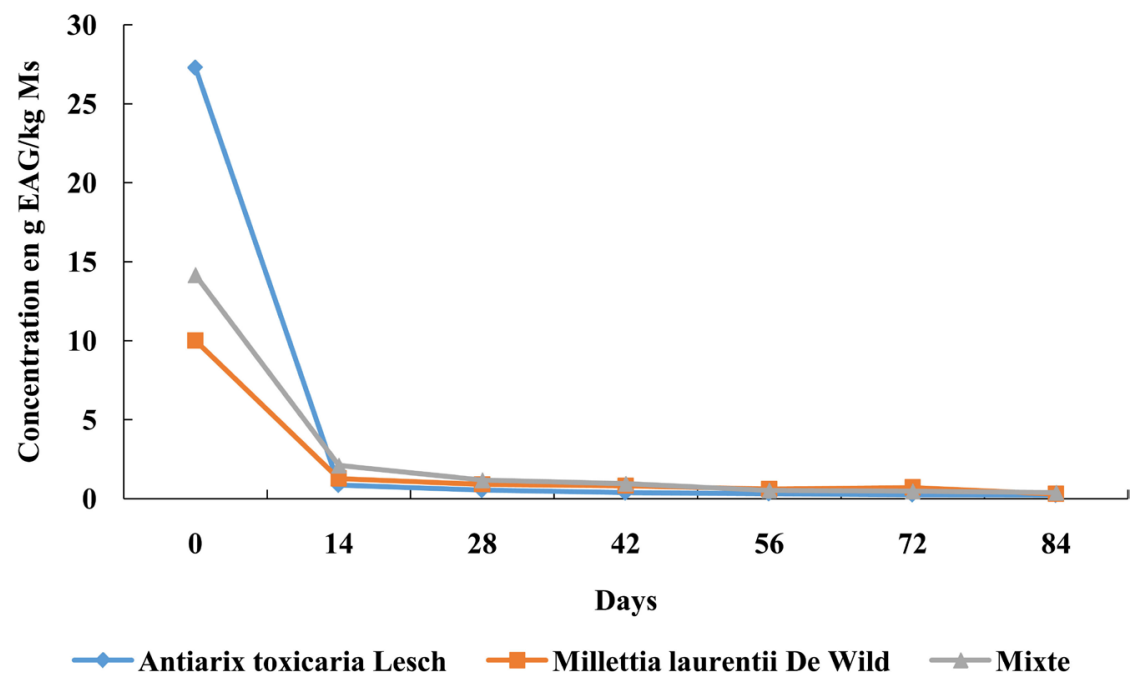

Figure 7. Trends of the loss of the polyphenols during experimental period. 


\section{Discussion}

\subsection{Chemical Transformation of Decaying Litter}

Following the reasoning of Wagner and Bladt (1996) the yellow-orange and yellow-green fluorescences highlighted in the initial litters of Antiaris toxicaria Lesch and Millettia laurentii De Wild after exposure of the plate to the UV-366 nm lamp, would be attributed to the derivatives of Quercetol and kaempferol (Figure 8 and Figure 9) and would be derived respectively from the substitution ortho-di hydroxy in position $3^{\prime}$ and 4 ' on the B-Ring of the Flavonoid and a substitution of a hydroxyl in position 4' on the B-Ring of the Flavonoid. The

Table 2. Specific decay rate $(k s)$ of each chemical compound in studied leaf litters, derived from the single exponential decay model fitted to the data on concentration loss of each compound.

\begin{tabular}{|c|c|c|c|c|c|c|c|c|c|}
\hline \multicolumn{10}{|c|}{ Decay rate chemistry compounds $\left(\mathrm{k}_{\mathrm{s}}\right.$ values weeks $\left.{ }^{-1}\right)$} \\
\hline & \multicolumn{3}{|c|}{ Reducing sugars } & \multicolumn{3}{|c|}{ Polyphenols } & \multicolumn{3}{|c|}{ Flavonoids } \\
\hline 2 & 0.62 & 0.69 & 0.54 & 1.03 & 1.73 & 0.96 & 0.61 & 1.36 & 0.98 \\
\hline 4 & 0.34 & 0.36 & 0.34 & 0.6 & 0.99 & 0.62 & 0.43 & 1.23 & 0.71 \\
\hline 6 & 0.24 & 0.26 & 0.23 & $\underline{0.42}$ & 0.72 & 0.45 & 0.42 & 0.86 & 0.51 \\
\hline 8 & 0.20 & 0.20 & 0.18 & 0.35 & 0.55 & 0.41 & 0.40 & 0.86 & 0.53 \\
\hline 10 & 0.16 & 0.16 & 0.16 & $\underline{0.26}$ & 0.47 & 0.34 & 0.34 & 0.75 & 0.42 \\
\hline 12 & 0.14 & 0.15 & 0.15 & 0.29 & 0.40 & 0.30 & 0.35 & 0.72 & 0.41 \\
\hline
\end{tabular}<smiles>O=c1c(O)c(-c2ccc(O)c(O)c2)oc2cc(O)cc(O)c12</smiles>

Figure 8. Structure 3' 4', 5, 7-trihydroxyisoflavonol: Quercetol.<smiles>O=c1c(O)ccccc1-c1ccccc1</smiles>

Figure 9. 3' 4', 5, 7-trihydroxyisoflavonol: Kaempferol. 
green-clear fluorescences highlighted in the initial litter of Antiaris toxicaria Lesch would be assimilated to the hydroxy cinnamiques derivatives, respectively, to the Chlorogenic or para-coumaric acid derivatives.

The initial chemical composition varied largely across the studied leaf litters, especially in terms of reducing sugar, flavonoids and polyphenols. Reducing sugar compounds were dominant organic compounds and varied less across species than other measured organic chemical compounds. The analyses showed that decomposition litters studied was accompanied by loss and chemical transformation of the organic compounds found into the litters' sample. These observations agreed with earlier studies conducted in a West African tropical forest and British Columbia (Prescott et al., 2004 and Guendehou et al., 2014). Guendehou et al. (2014) reported leaf litters were dominant cellulose and hemicelluloses compounds. In a Congolese plantation Eucalyptus, in Republic of Congo, Ngao et al. (2009) determined also highest Cellulose and Hemicelluloses concentrations than phenolic compounds (water-soluble phenol and water-insoluble phenol) in various eucalypt litters. All initial chemistry concentrations of these studies were higher than our data. These discrepancies may be explained by differences in the studied species, methods applied, and environmental factors such as climate, soil type.

High reducing sugars in remaining litter confirm that reducing sugars control the decomposition of the leaf litters studied. Several authors stressed the importance of carbohydrates in determining the initial rate of mass loss (Bernhard-Reversat, 1993; Arrigo et al., 2002). But, Prescott et al. (2004) showed that after4 to 5 years of decomposition no initial chemical parameter of litters is good predictor of residual mass.

In our study, edapho-climatic conditions were similar. The difference in litter samples decomposition was due to quality of litter studies. In this way, the losses of concentrations in the decomposition litters were associated to the leaching of soluble organic compounds and a high microbial mineralization (Austin \& Vitousek, 2000; Jacob et al., 2009; Ngao et al., 2009), which include the C mineralization rates. Relationship between $\mathrm{C}$ mineralization, mass loss and litter quality were developed (Bernhard-Reversat \& Schwartz, 1997; Bernhard-Reversat et al., 2001; Berg \& McClaugherty, 2008). Carbon is an important constituent in litter and soil C fluxes is usually related to leaf litter decomposition (Jeyanny et al., 2015).

In addition, highest concentration losses two (02) weeks after litter decay taken with almost total elimination of all phenolic compounds, being $80 \%$ and $89 \%$ of the initial concentration loss in flavonoids and polyphenols, respectively. The chromatographic profile of the decaying litters and results of compounds rate decreasing (values $\mathrm{k}_{\mathrm{s}}$ ) were agreed with these trends.The outstanding results from this study may suggest phenolic compounds are highly soluble, vulnerable to leaching by rain and easily utilized for microbial growth, giving higher $k_{s}$ values than reducing sugar across the species. Bernhard-Reversat et al. (2003) showed in Eucalypt litter a very sharp decrease of $25 \%$ - $48 \%$ in soluble phenolic 
compounds during the first days ( 1 or few days) compared to insoluble phenolics. Other authors reported the fast disappearance of phenolics (including methanol and water soluble) within the first week or month (Bernhard-Reversat, 1993; Maity \& Job, 1999; Sampaio et al., 2001). However, the degradation of phenolics in leaf litter is due to high concentration of oxidizing enzymes, particularly phenolases, in leaves, over and above microbial processes (Harborne, 1997 and Bernhard-Reversat et al., 2003).

\subsection{Relationship between Mass Losses and Chemistry Decay Rate}

There is an interaction between changes in concentrations of chemical compounds and rate of litters decay. As the decay rate decreases, degradation of chemical compounds slows down. It is important to see that the maximum decomposition rate of the litters studied (Antiaris toxicaria, Millettia laurentii and mixed litters) is was obtained over the same period as the maximum loss of chemical compounds of these litters; covering the two first or four weeks of decay. If two major phases of litter decomposition were detected during litter weight loss (Bernhard-Reversat et al., 2000; Kimbangui, 2002), the analyses of foliar litters of Antiaris toxicaria, Millettia laurentii and mixed litters also have presented two important phases in the degradation of chemical compounds (reducing sugars, flavonoids and polyphenols); the fastest phase have a time of two weeks.

\subsection{Chemical Compound Impacts to Decay Litter Studies}

The results obtained in our study present for the litters of Millettia laurentii slightly higher concentrations of reducing sugars and significantly lower in phenolics compounds compared with the litters of Antiaris toxicaria. All initial chemical compounds resulted to the Reducing sugar/Flavonoids and Reducing sugar/Polyphenols ratios lower in Antiaris toxicaria than Millettia laurentii. However, the rate of decomposition (including mass losses and chemical compound losses) of Millettia laurentii De Wild litters is lower compared to the rate of decomposition of Antiaris toxicaria Lesch. It seems to impose that the high Flavonoid and Polyphenol content in Antiaris toxicaria litters did not limit their decomposition. Whereas several authors have demonstrated that the litters that is rich in labile compounds (sugar, amino acids, etc.) are readily biodegradable with a high rate of decomposition (Guendehou et al., 2014; Tardif, 2014), in contrast to a litter rich in recalcitrant compounds (lignin and secondary metabolites). In this fact reducing sugar and phenolics compounds don't be enough to close to the variability about decay rate litters studies. Another explanation of these differences may be into the physical properties of litters at one part, the flux of nitrogen during decomposition another part and at last by the taxonomy of species. In fact, Nitrogen is indeed the limiting factor of decay because it serves to synthesize proteins for the growth of microbial biomass and thus determines the biological activity of soil (Mangenot, 1980). The taxonomy is one of 
the main factors influencing litter decomposition, as it determines the nature and abundance of phenolic compounds for a species (Bernhard-Reversat et al., 2000).

\section{Conclusion}

The present study allowed to study the link between litters decomposition and leaching of chemical organic compounds of the litters of the mains species of the natural forest of the city of Brazzaville. The highest decay rate was reported to Antiaris toxicaria. Water soluble compounds (Reducing sugars, Flavonoids and Polyphenols) of these litters were significantly leached from litters two weeks after the deposit on the field. Reducing sugars are the principal organic chemical compounds of litters Antiaris toxicaria and Millettia Laurentii, on account of their abundance. The rainy season appeared to be an important period in the $C$ cycling of carbon by the fact of leaching of soluble carbon present in the main components of litters.

\section{Conflicts of Interest}

The authors declare no conflicts of interest regarding the publication of this paper.

\section{References}

Anderson J. M., \& Swift, M. J. (1983). Decomposition in Tropical Forests. In S. L. Sutton, T. C. Whitmore, \& A. C. Chadwick (Eds.), Tropical Rain Forest: Ecology and Management (pp. 287-308). Oxford: Special Publication No. 2 of the British Ecological Society, Blackwell Scientific Publications.

Arrigo, N. M., Jimenez, M. P., Effron, D., \& Defrieri, R. (2002). Carbon Respiration of a Forest Soil and Its Relation to the Litter Fall. Agricultural Technology, 62, 331-338.

Austin, A. T., \& Vitousek, P. M. (2000). Precipitation, Decomposition and Litter Decomposability of Metrosideros polymorpha in Native Forests on Hawaii. Journal of Ecology, 88, 129-138. https://doi.org/10.1046/j.1365-2745.2000.00437.x

Babel, U. (1971). Gliederung und Beschreibung des humusprofils in mitteleuropäischen Wäldern. Geoderma, 5, 297-324. https://doi.org/10.1016/0016-7061(71)90041-3

Bachelier, G., \& Gavinelli, R. (1966). Dosage global des Glucides du sol par les méthodes colorimétriques à l'antrhone et à l'orcinol. Cahier Orstom Série Pédologique, 4, 97-103.

Bargali, S. S., Singh, S. P., \& Singh, R. P. (1993). Pattern of Weight Loss and Nutrient Release in Decomposing Leaf Litter in an Age Series of Eucalypt Plantations. Soil Biology and Biochemistry, 25, 1731-1738. https://doi.org/10.1016/0038-0717(93)90177-D

Berg, B., \& Mcclaugherty, C. (2008). Plant Litter: Decomposition, Humus Formation, Carbon Sequestration (2nd Edition, 338 p). Finland: Springer.

https://doi.org/10.1007/978-3-540-74923-3

Bernhard-Reversat, F. (1993). Dynamics of Litter and Organic Matter at the Soil-Litter Interface in Fast-Growing Tree Plantations on Sandy Ferrallitic Soils (Congo). Acta Oecologica, 14, 179-195.

Bernhard-Reversat, F., \& Schwartz, D. (1997). Change in Lignin Content during Litter Decomposition in Tropical Forest Soils (Congo): Comparison of Exotic Plantations 
and Native Stands. Earth and Planetary Sciences, 325, 427-432.

Bernhard-Reversat, F., Huttel, C., \& Lemee, G. (1979). Structure et Fonctionnement des Ecosystèmes de la Forêt Pluvieuse Sempervirente de Côte d'Ivoire. In UNESCO-PNUD (Eds.), Ecosystèmes forestiers tropicaux (pp. 606-625). Paris.

Bernhard-Reversat, F., Loumeto, J. J., \& Laclau, J. P. (2001). Litterfall, Litter Quality and Decomposition Changes with Eucalypt Hybrids and Plantation Age. In F. Bernhard-Reversat (Ed.), Effect of Exotic Tree Plantations on Plant Diversity and Biological Soil Fertility in the Congo Savanna with Special Reference to Eucalypts (pp. 23-29, Chap. 3). Bogor, Indonésie: Center for International Forestry Research.

Bernhard-Reversat, F., Main, G., Holl, K., Loumeto, J., \& Ngao, J. (2003). Fast Disappearance of the Water-Soluble Phenolic Fraction in Eucalypt Leaf Litter during Laboratory and Field Experiments. Applied Soil Ecology, 23, 273-278.

https://doi.org/10.1016/S0929-1393(03)00061-1

Bernhard-Reversat, F., Weighte, D., \& Harmand, J. M. (2000). Qualités des litières et décomposition dans les jachères naturelles. In R. Pontanier Ch. Floret. John Libbey Eurotext (Ed). La jachère en Afrique tropicale (pp. 194-203). Paris.

Bolund, P., \& Hunhammar, S. (1999). Ecosystem Services in Urban Areas. Ecological Economics, 29, 293-301. https://doi.org/10.1016/S0921-8009(99)00013-0

Cornelissen, J. H. C. (1996). An Experimental Comparison of Leaf Decomposition Rates in a Wide Range of Temperate Plant Species and Types. Journal of Ecology, 84, 573-582. https://doi.org/10.2307/2261479

de Wasseige, C., Tadoum, M., Eba'a Atyi, R., \& Doumenge, C. (2015). The Forests of the Congo Basin: Forests and Climate Change (128 p.). Weyrich.

Diallo, M. D., Mahama-Salehm, G. T., Diop, L., Wade, T. I., Niang, K., Diop, A., \& Guisse, A. (2016). Chute et décomposition de la litière de cinq espèces ligneuses et leur influence sur la bioweighte herbacee dans la zone nord Ferlo du Sénégal. Journal de la Recherche Scientifique de I'Université de Lomé, 18, 1-18.

Diallo, M. D., Saleh, M. M., Ndiaye, O., Aliou, D., \& Aliouguisse (2015). Influence de la décomposition de la nécro-masse des espèces végétales tropicales sur le $\mathrm{pH}$ et la structure génétique des communautés bactériennes d'un sol ferrugineux tropical au Sénégal. Journal of Applied Biosciences, 91, 8547-8558.

Dwyer, J. F., Schroeder, H. W., \& Gobster, P. H. (1991). The Significance of Urban Trees and Forests: Toward a Deeper Understanding of Values. Journal of Arboriculture, 17, 276-284.

FAO (2010). Global Forest Resources Assessment 2010. Rome: Food and Agriculture Organization.

Garay, I., Nazoa, S., \& Abbadie, L. (1986). Etude d'une litière forestière mixte à charme (Carpinus betulus L.) et à chêne (Quercus sessiliflora S.). Acta Ecologica, Ecol. Gener. 7, 151-169.

Garty, J., Kauppi, M., \& Kauppi, A. (1996). Accumulation of Airbone Elements from Vehicles in Transplanted Lichens in Urbain Sites. Journal of Environmental Quality, 25, 265-272. https://doi.org/10.2134/jeq1996.00472425002500020009x

Goma-Tchimbakala, J., \& Reversat, F. B. (2006). Comparison of Litter Dynamics in Three Plantations of an Indigenous Timber Species (Terminalia superb) and a Natural Tropical Forest in Mayombe, Congo. Forest Ecology and Management, 229, 304-313. https://doi.org/10.1016/j.foreco.2006.04.009

Guendehou, G. H. S., Liski, J., Tuomi, M., Mansourou-Moudachirou, S. B., \& Mäkipää, R. (2014). Decomposition and Changes in Chemical Composition of Leaf Litter of Five 
Dominant Tree Species in a West African Tropical Forest. Tropical Ecology, 55, 207-220.

Guo, L. B., \& Sims, R. E. H. (1999). Litter Decomposition and Nutrient Release via Litter Decomposition in New Zealand Eucalypt Short Rotation Forests. Agriculture Ecosystems and Environment, 75, 133-140. https://doi.org/10.1016/S0167-8809(99)00069-9

Harborne, J. B. (1997). Role of Phenolic Secondary Metabolites in Plants and Their Degradation in Nature. In G. Cadish, \& K. E. Giller (Eds.), Driven by Nature: Plant Litter Quality and Decomposition (pp. 67-74). Oxon: CAB International.

Hogan, S., Zhang, L., Li, J., Zoecklein, B., \& Zhou, K. (2009). Antioxidant Properties and Bioactive Components of Norton (Vitis aestivalis) and Cabernet Franc (Vitis vinifera) Wine Grapes, LWT. Food Science and Technology, 42, 1269-1274. https://doi.org/10.1016/j.lwt.2009.02.006

Huang, D. J., Chen, H. J., Lin, C. D., \& Lin, Y. H. (2005). Antioxidant and Antiproliferative Activities of Water Spinach (Ipomoea aquatica Forssk.) Constituents. Botanical Bulletin-Academia Sinica Taipei, 46, 99-106.

Ibrahima, A., Biyanzi, P., \& Halima, M. (2008). Changes in Organic Compounds during Leaf Litter Leaching: Laboratory Experiment on Eight Species of the Sudano-Guinea Savannas of Ngaoundere, Cameroun. Biogeosciences \& Forestry, 1, 27-33.

Ifo, A., \& Nganga, D. (2011). Litterfall, Accumulation and Decomposition in Forest Groves Established on Savannah in the Plateau Teke, Central Africa. Journal of Environmental Science and Technology, 4, 601-610.

Ifo, S. A. (2010). Apports de carbone au sol et stocks dans deux types forestiers (forêtgalerie et forêtsecondaire) des plateauxtékés (194 p.). Thèse, Brazzaville: Université Marien Ngouabi.

Ifo, S. A., Malonga, M. U., Milandou, J., Madingou, M. P., Mavoungou, N., Nzingoula, S., \& Binsangou, S. (2018). Litter Fall, Standing Litter and Leaves Decomposition within Urbain Tropical Forest of Zoological Park of Brazzaville, Republic of the Congo. Research Journal of Botany, 13, 1-10.

Ifo, S. A., Moutsambote, J.-M., Koubouana, F., Ndzai, S. F., Bouetou-Kadilamio, L. N. O., Mampouya, H., Jourdain, C., Bocko, Y., Mantota, A. B., Mbemba, M., Mouanga-Sokath, D., Odende, R., Mondzali, L. R., Mampouya Wenina, Y. E., Ouissika, B. C., \& Loumeto, J. J. (2016). Tree Species Diversity Richness and Similarity in Intact and Degrated Forest in the Tropical Rainforest of the Congo Basin: Case of the Forest of Likouala in the Republic of Congo. International Journal of Forestery Research, 2016, Article ID: 7593681.

IPCC (2006). 2006 IPCC Guidelines for National Greenhouse Gas Inventories. IGES.

Jacob, M., Weland, N., Platner, C., Schaefer, M., Leuschner, C., \& Thomas, F. M. (2009). Nutrient Release from Decomposing Leaf Litter of Temperate Deciduous Forest Trees along a Gradient of Increasing Tree Species Diversity. Soil Biology and Biochemistry, 41, 2122-2130. https://doi.org/10.1016/j.soilbio.2009.07.024

Jeyanny, V., Wan-Rasidah, K., Ahmad-Husni, M. H., Siva-Kumar, B., Muhammad, F. S., \& Arifin, A. (2015). Leaf Litter Decomposition and Soil Carbon Dioxide Fluxes across Climatic Gradient in Tropical Montane and Lowlands Forests. Journal of Tropical Forest Science, 27, 472-487.

Jia, Z., Tang, M., \& Wu, J. (1999). The Determination of Flavonoid Contents in Mulberry and Their Scavenging Effects on Superoxide Radicals. Food Chemistry, 64, 555-559.

Kalburtji, K. L., Mosjidis, J. A., \& Mamolos, A. P. (1999). Litter Dynamics of Low and 
High Tannin Secea lespeza Plants under Field Conditions. Plant Soil, 208, 271-281. https://doi.org/10.1023/A:1004577624435

Kim, B., Chun, O., Kim, Y., Moon, H., \& Lee, C. (2003). Quantification of Polyphenolics and Their Antioxidant Capacity in Fresh Plums. Journal of Agricultural and Food Chemistry, 51, 6509-6515.

Kimbangui, A. (2002). Production, Accumulation et Décomposition de la litière dans deux forêts à Okoumé (Aucoumea klaineana) de la zone de youbi (14 p.). Brazzaville: Université MarienNgouabi.

Koubouana, F., Ifo, S. A., Loupet, L. B. M., \& Ndinga, E. (2016). Diversité floristique et dynamique de reconstitution de la forêt du Parc Zoologique sous plantatations à Eucalyptus à Brazzaville, Congo. International Journal of Biological Sciences, 10, 609-619.

Lewis, S. L., Lopez-Gonzales, G., Sonké, B., Affum-Baker, T. R., Ojo, J. O., Phillips, O. L., Reistsma, J. M., White, L., Comiskey, J. A., Djuikouo, K., Ewango, M. N., Feldpausch, C. E. N., Hamilton, T. R., Gloor, A. C., Hart, M., Hladik, T., Lloyd, A., Lovett, J., Makana, J. C., Malhi, J. R., Mbago, Y., Ndangalasi, F. M., Peacock, H. J., Peh, K. S., Sheil, D., Sunderland, T., Swaine, M. D., Taplin, J., Taylor, D., Thomas, S. C., Votere, R., \& Wöll, H. (2009). Increasing Carbon Storage in Intact African Tropical Forests. Nature, 457, 1003-1006. https://doi.org/10.1038/nature07771

Loumeto, J. J. (2002). Le système litière des forêts à peuplements d'Okoumé (Aucoumeaklaineana). Exemple de deux sites congolais: La forêt du Chaillu et la forêt du littoral (Vol. 6, 159 p.). Thèse, Paris: Université Pierre et Marie Curie.

Maity, S. K., \& Joy, V. C. (1999). Impact of Antinutritional Chemical Compounds of Leaf Litter on Detritivore Soil Arthropod Fauna. Journal of Ecobiology, 11, 193-202.

Mangenot, F. (1980). Les litières forestières: Signification écologique et pédologique. Litièresforestières. (pp. 339-355).

Ngao, J., Bernhard-Reversat, F., \& Loumeto, J. L. (2009). Changes in Eucalypt Litter Quality during the First Three Months of Field Decomposition in a Congolese Plantation. Applied Soil Ecology, 42, 191-199. https://doi.org/10.1016/j.apsoil.2009.03.008

Olson, J. S. (1963). Energy Storage and the Balance of Producers and Decomposers in Ecological Systems. Ecology, 44, 322-331. https://doi.org/10.2307/1932179

Pansu Marc (1992). Les sucres neutres dans les sols: Opportunité et tentatives d'amélioration de leur détermination (25 p.). Centre de Montpellier.

Prescott, C. E., Vesterdal, L., Preston, C. M., \& Simard, S. W. (2004). Influence of Initial Chemistry on Decomposition of Foliar Litter in Contrasting Forest Types in British Columbia.

Sabin Nguedehou, G. H., Liski, J., Tuomi, M., Moudachirou, M., Sinsin, B., \& Makipa, R. (2014). Decomposition and Changes in Chemical Composition of Leaf Litter of Five Dominant Tree Species in a West African Tropical Forest. Tropical Ecology, 55, 207-220.

Sampaio, A., Cortes, R., \& Leao, C. (2001). Invertebrate and Microbial Colonization in Native and Exotic Leaf Litter Species in a Mountain Stream. International Review of Hydrobiology, 86, 527-540. https://doi.org/10.1002/1522-2632(200107)86:4/5<527::AID-IROH527>3.0.CO;2-D

Segade, S., Rolle, L., Gerbi, V., \& Orriols, I. (2008). Phenolic Ripeness Assessment of Grape Skin by Texture Analysis. Journal of Food Composition and Analysis, 21, 599-607. https://doi.org/10.1016/j.jfca.2008.06.003 
Swift, M. J., Heal, O. W., \& Anderson, J. M. (1979). Decomposition in Terrestrial Ecosystems (372 p.). Studies in Ecology, Vol. 5, Blackwell Scientific Publications.

Tardif, A. (2014). Prédiction des taux de décomposition des litièresvégétales par les traits fonctionnelsagrégés (184 p.). Thèse, Université de Sherbrooke.

Taty, D. C., \& Mombouli, R. (1998). Etude qualitative et quantitative de la forêt du Parc Zoologique de Brazzaville (Congo) (50 p.). Brazzaville: Mémoire de fin de formation CAPES, ENS, Université Marien Ngouabi.

Torreta, N. K., \& Takeda, H. (1999). Carbon and Nitrogen Dynamics of Decomposing Leaf Litter in a Tropical Hill Evergreen Forest. European Journal of Soil Biology, 35, 57-63. https://doi.org/10.1016/S1164-5563(99)00111-9

Wagner, H., \& Bladt, S. (1996). Plant Drug Analysis, a Thin Layer Chromatography Atlas (2nd ed.). Berlin: Springer.

Waring, R. H., \& Schlesinger, W. H. (1985). Forest Ecosystems: Concepts and Management (pp. 181-210). New York: Academic Press.

Waterhouse, A. L. (2001). Determination of Total Phenolics. Current Protocols in Food Analytical Chemistry.

Zeller, B. (1998). Contribution à l'étude de la décomposition d'une litière de hêtre, lalibération de l'azote, sa minéralisation et son prélèvement par le hêtre (Fagussylvatica L.) dans une hêtraie de montagne du bassin versant du Strengbach (Haut-Rhin) (146 p.). Thèse l'Université Henri Poincaré, Nancy-I.

Zouaoui, I., Abbes, C., Hasnaoui, F., \& Hasnaoui, B. (2013). Dynamique de la decomposition des litières dans les sols forestiers. Thèse de l'université de Tunis. Annales de l'Inrgref, 18, 63-75. 